\title{
The Influence of Alloy Composition and Microstructure on the Corrosion Behaviour of Cu-Ni Alloys in Seawater
}

\author{
Einfluß von Legierungszusammensetzung und Mikrogefüge auf das \\ Korrosionsverhalten von CuNi-Legierungen in Meerwasser
}

\author{
L. J. P. Drolenga* F. P. IJsseling* and \\ B. H. Kolster ${ }^{\star \star}$
}

The aim of the study was to relate the general corrosion behaviour of CuNi 10-alloys in seawater with its iron content and microstructure. To that end the microstructure of four commercial alloys with various Fe-contents (1.20-1.78\%) and three laboratory melted alloys with various Fe-contents $(1.5-2.5 \%)$ were investigated in the as delivered state and after three different heat treatments. Samples of these alloys were exposed to flowing natural seawater. During exposure electrochemical measurements were performed. After exposure the weight loss was determined. Moreover, for a number of samples the corrosion products were analysed by means of electron microprobe analysis.

Irrespective of the $\mathrm{Fe}$-content, the presence of discontinuous precipitates in the laboratory melted alloys turned out to be detrimental with regard to general corrosion. To a less extent this also holds for alloys with high concentrations of continuous precipitates, as observed for iron contents of 2 and $2.5 \%$. The precipitate free alloys as well as the ones containing low concentrations of continuous precipitates because of low Fe-concentrations $(\leqslant 1.5 \% \mathrm{Fe})$ do show a good corrosion behaviour.

The corrosion behaviour of commercial CuNi $10 \mathrm{Fe}$ in the as received condition was generally comparable with that of laboratory melted alloys with continuous precipitates. The corrosion rates of the former do not exceed those of the latter, which are very low for practical applications. Finally the corrosion behaviour of five laboratory melted CuNi 5 alloys, containing up to $4 \% \mathrm{Fe}$ in solution, was investigated. It turned out that their reciprocal polarisation resistance in the steady state situation is lower than those for the $\mathrm{CuNi} 10 \mathrm{Fe}$ alloys.
Ziel der vorliegenden Untersuchung war dic Suche nach einem Zusammenhang zwischen dem Korrosionsverhalten von $\mathrm{CuNi} 10$ in Meerwasser und dem Eisengehalt sowie dem Mikrogefüge von vier handelsüblichen Legierungen mit Eisengehalten zwischen 1,20 und $1,78 \%$ und drei experimentellen Schmelzen mit Eisengehalten zwischen 1,5 und $2.5 \%$ im Lieferzustand und nach drei verschiedenen Wärmebehandlungen untersucht. Proben dieser Legierungen wurden der Einwirkung von strömendem Meerwasser ausgesetzt, wobei clektrochemische Messungen durchgeführt wurden; nach Abschluß der Versuche wurde der Gewichtsverlust ermittelt. Außerdem wurden für mehrere Proben die Korrosionsprodukte mit Hilfe der Elektronensondenmikroanalyse analysicrt. Unabhängig vom Ejsengehalt erweist sich das Auftreten von diskontinuierlichen Ausscheidungen in den experimentellen Schmelzen als ungünstig für das Korrosionsverhalten. Das gilt, wenn auch in geringerem Ausma $B$, auch für Legierungen mit hohen Anteilen an kontinuicrlichen Ausscheidungen, wie sie bei 2 und $2,5 \%$ Eisen vorliegen. Die ausscheidungsfreien Legierungen, die wegen der niedrigen Eisengehaltc (unter $1.5 \%$ ) nur geringe Anteile an kontinuierlichen Ausscheidungen enthalten, zeigen gutes Korrosionsverhalten. Das Verhalten der handelsüblichen CuNi $10 \mathrm{Fc}$-Legierungen im Lieferzustand war im allgemeinen vergleichbar mit dem von experimentellen Legierungen, die kontinuierliche Ausscheidungen enthalten. Die Korrosionsgeschwindigkeit der erstgenannten liegt nicht höher als die der zuletzt genannten und ist für praktische Anwendungen sehr gering. Abschließend wurde das Korrosionsverhalten von 5 experimentellen Schmelzen des Typs CuNi 5 mit bis zu 4\% Eisen in fester Lösung untersucht. Hierbei ist der reziproke Wert des Polarisationswiderstands unter stationären Bedingungen niedriger als im Falle der $\mathrm{CuNi} 10 \mathrm{Fe}$-Legierungen.

\section{Introduction}

Corrosion problems give rise to economical losses up to some percent of the GNP [1]. Thus, designing technical installations requires the proper precautions with respect to corrosion. In particular the choice of the materials, the construction itself and the choice of the protective measures are of para-

\footnotetext{
* Ir. L. J. P. Drolenga, Prof. Dr. F. P. IJsseling, Corrosion Laboratory, Royal Netherlands Naval College Den Helder, The Netherlands.

** Prof. Dr.-Ir. B. H. Kolster, Twente Technical University, Enschede/Metaalinstituut TNO, Postbus 541, NL-7300 AM Apeldoorn.
}

mount importance. These considerations also apply to equipment, in which seawater is used, such as heat exchangers, piping systems and desalination apparatus. One of the alloys being used for such applications is $\mathrm{CuNi} 10 \mathrm{Fe}$ standardized in DIN 17664, ASTM B 111 and BS2871. Although much research has been devoted to the corrosion behaviour of this type of alloys in seawater, the reaction mechanism is still not known $[1-4]$. One of the conclusions reached so far is the pronounced influence of the Fe-content and the microstructure of the alloy on the corrosion behaviour [5-11].

The aim of this investigation was to extend the study of the effect of $\mathrm{Fe}$-content and microstructure of $\mathrm{CuNi} 10$-alloys on the corrosion behaviour in seawater. 
In order to achieve this, definite microstructures have been produced by special heat treatments. It has to be pointed out that some of these do not occur during fabrication or application of commercial alloys. For this work these heat treatments were of special interest to produce different and well defined microstructures. In addition the corrosion rates of these alloys are compared to those of CuNi 5 alloys with high contents of $\mathrm{Fe}$ in solution. These materials have been developed as a possible substitute for $\mathrm{CuNi} 10 \mathrm{Fe}$ alloys $[12,13]$. The development of these alloys is based on the concept that increasing contents of dissolved iron will increase the corrosion resistance in seawater $[6,7,9]$.

As in the standard $\mathrm{CuNi} 10$ and $\mathrm{CuNi} 5$ alloys the solubility of $\mathrm{Fe}$ is restricted, the $\mathrm{Fe}$ solubility in the modified $\mathrm{CuNi} 5$ alloys is raised by adding aluminium and in some cases manganese as well.

\section{Experimental}

\subsection{Materials}

The following groups of alloys have been investigated:

a) Commercial CuNi $10 \mathrm{Fe}$ tubes with four different Fe-contents ${ }^{1)}$

b) Laboratory melted CuNi 10 alloys containing 1.5, 2 and $2.5 \% \mathrm{Fe}$ prepared from technically pure copper and electrolytically pure nickel, iron and manganese. The ingots were homogenized by heating at $850^{\circ} \mathrm{C}$ during 24 hours, turned on a lathe and finally extruded to pipe. As in the former case the outer diameter of the pipe was $20 \mathrm{~mm}$ and the wall thickness $1 \mathrm{~mm}^{2}$;

c) Five pure CuNi 5 alloys with addition of aluminium and in some cases manganese, as well as $\mathrm{CuNi} 10 \mathrm{Fe} 1.4$ for comparative purposes. These alloys were produced in the laboratory as rods ${ }^{3)}$. The production procedure and the microstructure are described in [12].

In Table 1 the chemical composition of the alloys is given. The designation pure is used for the laboratory melted alloys.

Table 1. Chemical composition of the alloys in wt. \%

Tabelle 1. Chemische Zusammensetzung der Legierungen in Gew.-\%

\begin{tabular}{lllllll}
\hline Material & Designation & $\mathrm{Fe}$ & $\mathrm{Al}$ & $\mathrm{Mn}$ & $\mathrm{Ni}$ & $\mathrm{Cu}$ \\
\hline Commercial & & & & & & \\
CuNi 10 Fe & CuNi 10Fe 1.2 & 1.20 & - & 0.70 & 10.01 & bal. \\
& CuNi 10Fe 1.36 & 1.36 & - & 0.72 & 9.9 & bal. \\
& CuNi 10Fe 1.51 & 1.51 & - & 0.68 & 10.1 & bal. \\
& CuNi 10 Fe 1.78 & 1.78 & - & 0.74 & 10.7 & bal. \\
Pure CuNi 10Fe CuNi 10 Fe 1.5 & 1.5 & - & 0.65 & 9.8 & bal. \\
& CuNi 10 Fe 2.0 & 1.9 & - & 0.74 & 9.5 & bal. \\
& CuNi 10Fe 2.5 & 2.4 & - & 0.76 & 9.6 & bal. \\
Pure CuNi 5 Fe & 37 & 3.3 & 5.1 & 2.1 & 5.0 & bal. \\
& 43 & 3.3 & 5.2 & 5.4 & 5.0 & bal. \\
& 47 & 3.3 & 3.2 & $<0.1$ & 5.0 & bal. \\
& 48 & 3.2 & 7.1 & $<0.1$ & 5.1 & bal. \\
& 50 & 4.2 & 7.2 & $<0.1$ & 5.0 & bal. \\
Pure CuNi 10Fe CuNi 10 Fe 1.4 & 1.44 & $<0.4$ & 0.57 & 10.1 & bal. \\
\hline
\end{tabular}

1) Made available by the Vereinigte Deutsche Metallwerke, Duisburg, Germany.

$\left.{ }^{2}\right)$ The ingots were produced by the Laboratory for Metallurgy, Technical University of Delft; the extrusion was performed by the Vereinigte Deutsche Metallwerke.

$\left.{ }^{3}\right)$ Made available by the Metaalinstituut TNO, Apeldoorn.

\subsection{Metallography}

The microstructures of the CuNi 10 Fe alloys (groups a and b) were determined in the as delivered state as well as after three different heat treatments, by means of optical microscopy, electron microscopy and electron microprobe analysis. The samples for optical microscopy were prepared by etching in ammonia under access of air. For electron microscopy thin foils were used, which were obtained by electrolytical polishing in a mixture of two parts concentrated methanol and one part concentrated nitric acid, at a temperature of $-30{ }^{\circ} \mathrm{C}$ After exposure several corrosion product layers were embedded and investigated by means of optical microscopy and electron microprobe analysis.

\subsection{Corrosion experiments}

The corrosion experiments which are reported in this paper concern the uniform corrosion of the alloys in flowing natural seawater. The experiments have been performed with test tubes, inserted in test loops, as well as with rotating cylindrical electrodes.

\subsubsection{Experiments with cylindrical electrodes}

The cylindrical electrodes (Fig. 1) were investigated in the measuring cell shown in Fig. 2. Thermostatted water circulating in the outer compartment of this measuring cell provides a constant temperature of the seawater in the inner compartment. The cylindrical electrode is clamped in a mounting which can be rotated by an electric motor and a V-drive. The platinum auxiliary electrode (Winkler type, diameter $40 \mathrm{~mm}$, height $60 \mathrm{~mm}$ ) is mounted as a cage around the rotating electrode. A saturated calomel electrode is connected via a Luggin capillary through the auxiliary electrode with the surface of the working electrode. The cylindrical electrodes were exposed during periods of $51 / 2$ weeks in natural seawater at temperatures of 20 and $30{ }^{\circ} \mathrm{C}$. The seawater in the measuring cell (about 1 l) was refreshed five times a week. The rotation speed of the electrodes was maintained at $1500 \mathrm{rpm}$, corresponding with a Reynolds number of 30.600 .

Before exposure the electrodes were prepared by grinding (grit 800 ), in a number of cases followed by polishing.

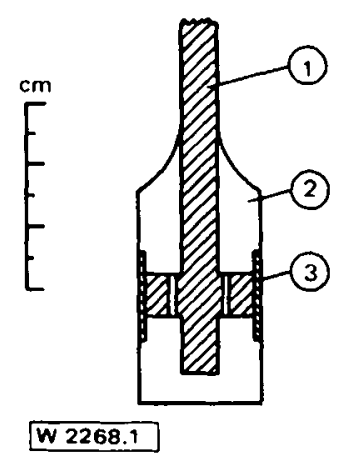

Fig. 1. Cross section of cylindrical electrode: 1. brass shaft; 2. epoxy resin body; 3. cylindrical sample, height $15 \mathrm{~mm}$ and diameter $20 \mathrm{~mm}$ Abb. 1. Schnitt durch eine zylindrische Elektrode: 1 - Messingschaft, 2 - Epoxyharzteil, 3 - zylindrische Probe mit $15 \mathrm{~mm}$ Höhe und $20 \mathrm{~mm}$ Durchmesser 


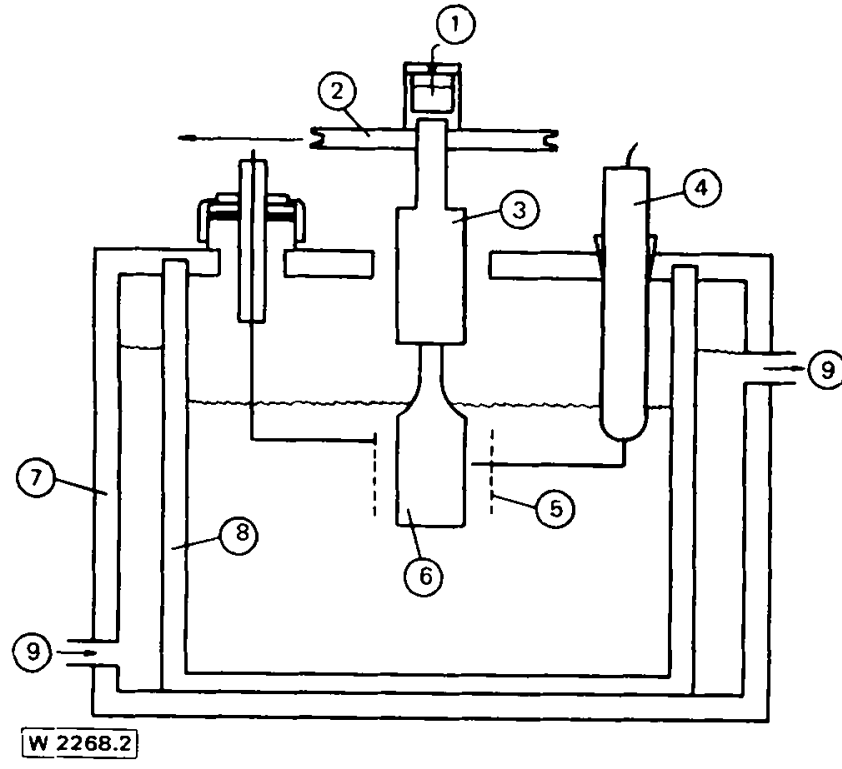

Fig. 2. Measuring vessel for exposure of rotating cylindrical electrodes to seawater: 1 . mercury contact for connection with working electrode; 2 . pulley drive; 3 . mounting for cylindrical electrode; 4 . saturated calomel reference electrode, provided with Luggin capillary; 5 . platinum auxiliary electrode; 6 . rotating cylindrical working electrode; 7. outer compartment; 8 . inner compartment; 9 . circulating thermostatted water

Abb. 2. Meßgefäß für die Prüfung der rotierenden zylindrischen Elektroden in Meerwasser: 1 - Quecksilberkontakt zum Anschluß an die Arbeitselektrode, 2 - Riemenantrieb, 3 - Haltevorrichtung für die zylindrische Elektrode, 4 - SCE-Bezugselektrode mit Luggin-Kapillare, 5 - Platinhilfselektrodc. 6 - zylindrische rotierende Arbeitsclektrode, 7 - Außenbehälter, 8 - Innenbehälter, 9 - thermostatisiertes Wasser

The following alloys were investigated:

a) commercial $\mathrm{CuNi} 10 \mathrm{Fe}$ as delivered, containing 1.2, 1.36, 1.51 and $1.78 \% \mathrm{Fe}$ (coded $1.2 \mathrm{~L}, 1.36 \mathrm{~L}, 1.5 \mathrm{~L}$ and $1.78 \mathrm{~L}$ );

b) pure $\mathrm{CuNi} 10 \mathrm{Fe}$, containing $1.5,2$ and $2.5 \% \mathrm{Fe}$ and commercial $\mathrm{CuNi} 10 \mathrm{Fe} 1.2$ after the following heat treatments: $-1000^{\circ} \mathrm{C} 4 \mathrm{~h} / \mathrm{WQ}$ (coded $1.2 \mathrm{H}, 1.5 \mathrm{H}, 2.0 \mathrm{H}, 2.5 \mathrm{H}$ )

$-1000{ }^{\circ} \mathrm{C} 4 \mathrm{~h} / \mathrm{WQ} / 650{ }^{\circ} \mathrm{C} 10^{\prime}$ (coded $1.2 \mathrm{CP}, 1.5 \mathrm{CP}, 2.0$ $\mathrm{CP}, 2.5 \mathrm{CP}$ )

- $1000^{\circ} \mathrm{C} 4 \mathrm{~h} / \mathrm{WQ} / 450^{\circ} \mathrm{C} 100 \mathrm{~h}$ (coded 1.2 DP, 1.5 DP, 2.0 DP, $2.5 \mathrm{DP}$ );

(the choice of these heat treatments will be explained in chapter 3)

c) pure CuNi 5 alloys (coded 37, 43, 47, 48 and 50) and CuNi 10 Fe 1.4 (coded $1.4 \mathrm{H}$ ).

Table 2 summarizes the experiments that were performed with rotating cylindrical electrodes. During each test series four to six electrodes were simultaneously exposed in separate measuring cells.

\subsubsection{Experiments with tube samples}

110 tube samples (length $120 \mathrm{~mm}$, outer diameter $20 \mathrm{~mm}$ ) were exposed to natural flowing seawater (flow velocity $1.5 \mathrm{~m} /$ $s, \operatorname{Re}=32500$, temperature $30^{\circ} \mathrm{C}$ ). All test samples were exposed simultaneously, using four identical test loops (Fig. 3 ). The seawater in the container was refreshed five times a week. CuNi $10 \mathrm{Fe}$ alloys containing $1.2,1.5,2.0$ and $2.5 \% \mathrm{Fe}$ have been exposed; the alloys were heat treated in the same

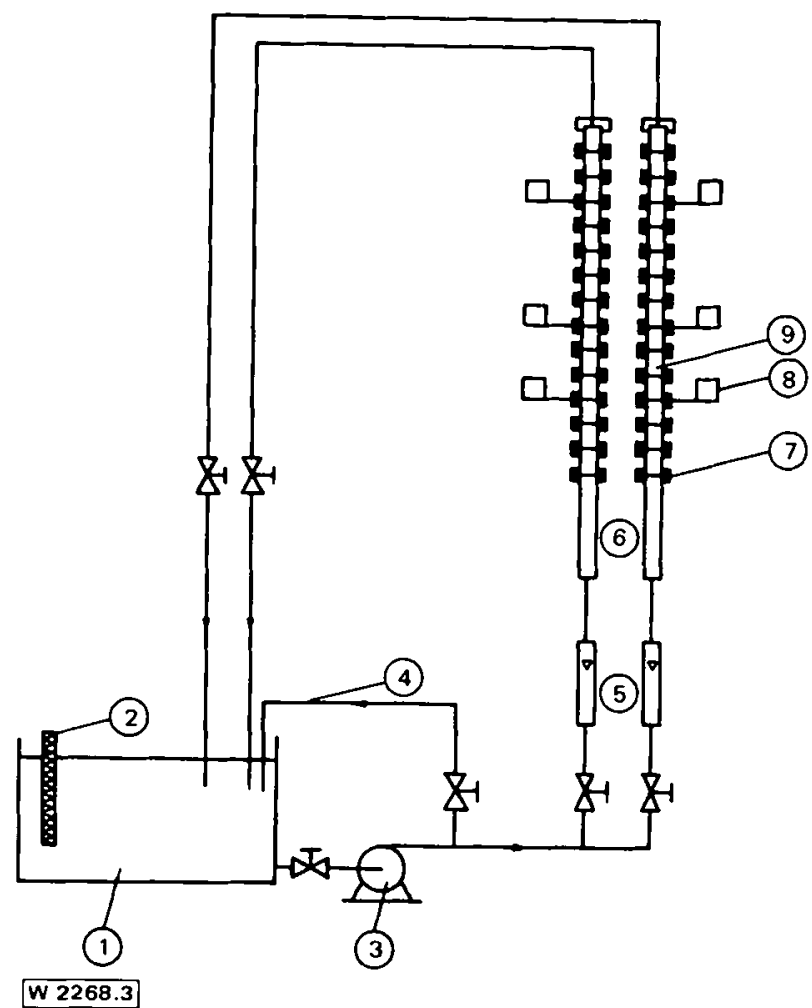

Fig. 3. Schematic view of equipment for tube experiments, including two measuring sections: 1 . PVC container for seawater; 2 . electrical heating element; 3 . pump; 4 . by-pass section; 5 . flow meters; 6 . measuring sections; 7. PVC couplings, provided with O-ring seals; 8 . the same, provided with connection to saturated calomel reference electrodes; 9 . test tubes (length $120 \mathrm{~mm}$, outer diameter $20 \mathrm{~mm}$ )

Abb. 3. Schematische Darstellung der Vorrichtung für die Untersuchungen an Rohren, einschließlich zweier MeBabschnitte: 1 - PVCBehälter für Meerwasser, 2 - elektrisches Heizelement, 3 - Pumpe, 4 By-pass, 5 - Strömungsmesser, 6 - Meßabschnitt, 7 - PVC-Kupplung mit O-Ringen, 8 - dito, mit Anschluß an SCE-Bezugselektroden, 9 Prüfrohr mit $120 \mathrm{~mm}$ Länge und $20 \mathrm{~mm}$ Außendurchmesser

way as mentioned before (only the 1.2 DP treatment was omitted). Out of each alloy type 10 test tubes were exposed. The test tubes were grit blasted and weighed before exposure. If the polarisation measurements indicated that a steady state was reached, which turned out to be the case after $580 \mathrm{~h}$ exposure, half of the test tubes was removed. The remaining test tubes were exposed up till $1350 \mathrm{~h}$. After exposure the tubes were weighed, before as well as after removal of the corrosion products. To remove the corrosion products the tubes were chemically cleaned with a 5\% hydrochloric acid solution, to which $4 \mathrm{~cm}^{3} / 1$ rhodine inhibiting solution was added.

\subsubsection{Electrochemical measurements}

The free corrosion potentials of the rotating cylindrical electrodes were measured manually 3 to 5 times a week during the exposure period. For the pipe samples a data logger system was used, measuring the potentials every two hours. The polarisation resistance of the samples was also measured 3 to 5 times a week. For the rotating cylindrical electrodes a potentiostatic technique was used, applying pulses of $2 \mathrm{mV}$ in anodic and cathodic direction during $4 \mathrm{~min}$. The pipe samples were measured galvanostatically, applying anodic and cathodic currents of $25 \mu \mathrm{A}$ during $4 \mathrm{~min}$. 


\section{Results}

\subsection{Metallography}

\subsubsection{Commercial alloys}

Electron microprobe line scans for $\mathrm{Cu}, \mathrm{Ni}$ and $\mathrm{Fe}$, perpendicular to the tube axis, were taken over a length of $55 \mu \mathrm{m}$ at

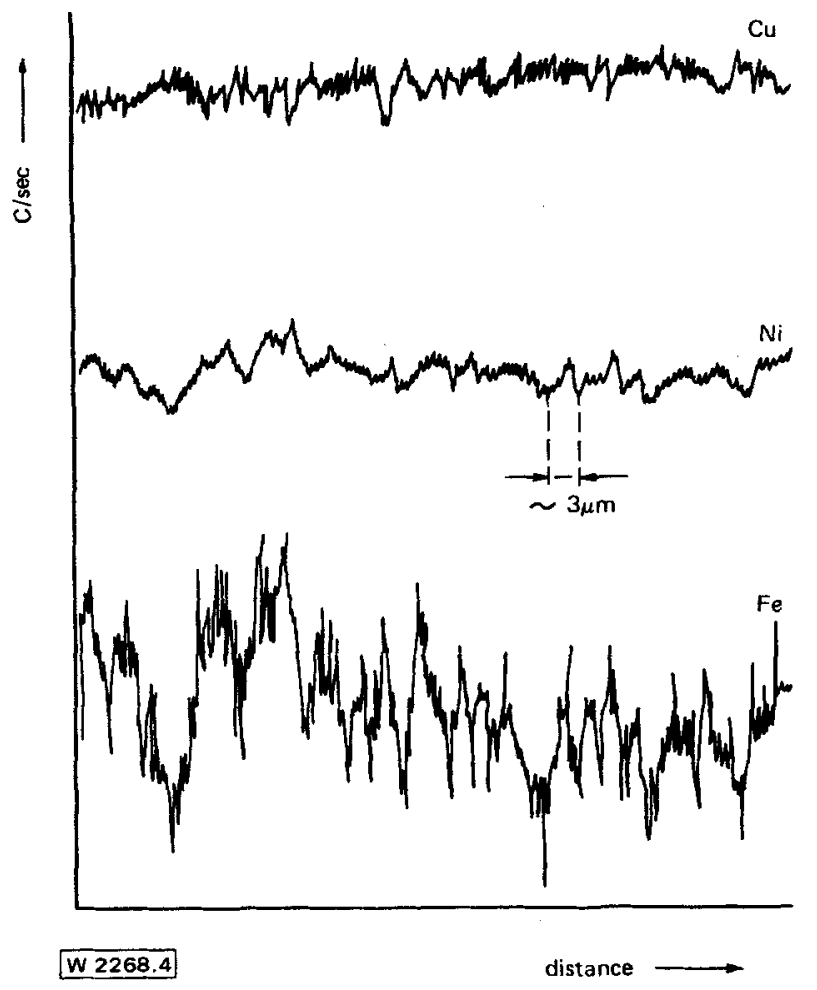

Fig. 4. Linescans of $\mathrm{Cu}, \mathrm{Ni}$ and $\mathrm{Fe}$ at the inner side of a sectioned $\mathrm{CuNi} 10 \mathrm{Fe} 1.78$ tube

Abb. 4. Linienabtastung für $\mathrm{Cu}, \mathrm{Ni}$ und $\mathrm{Fe}$ an der Innenseite eines aufgeschnittenen Rohrs aus CuNi 10 Fe 1,78

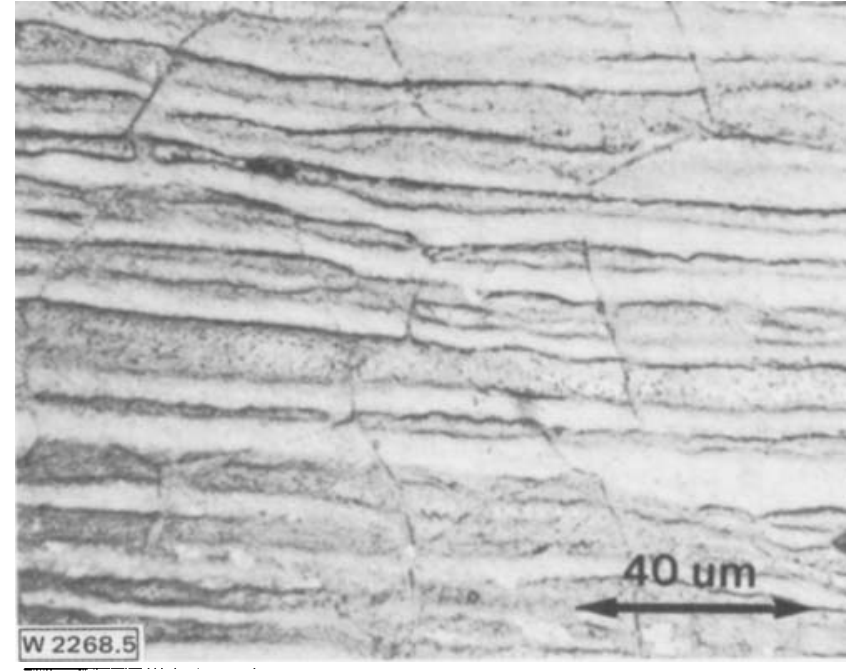

Fig. 5. Microstructure of commercial CuNi 10Fe 1.36; $600: 1$

Abb. 5. Mikrogefüge von handelsüblichem $\mathrm{CuNi} 10 \mathrm{Fe}$ 1,36; $600: 1$

the inner side, in the center and the outher side of the crosssection of the tube sample. Figure 4 shows an example of a scan for CuNi 10 Fe 1.78. The profiles of nickel and iron coincide and are opposite to the copper profile. The alternating $\mathrm{Ni} /$ $\mathrm{Fe}$ - rich and $\mathrm{Ni} / \mathrm{Fe}$-poor regions correspond with segregation bands (cf. Fig. 5).

For each element the maximum and minimum concentrations in the linescan have been expressed as the so called kfactor (minimum concentration/maximum concentration). For a homogeneous material without precipitates or segregation the $\mathrm{k}$-factor equals one. The $\mathrm{k}$-factors determined in this way, are shown in Table 3.

\subsubsection{Pure CuNi 10 Fe-alloys}

After homogenization of the ingot by heating $24 \mathrm{~h}$ at $850^{\circ} \mathrm{C}$ the original dendritic structure had disappeared and recrystal-

Table 2. The test series for the rotating cylindrical electrode experiments $(G=$ ground, $P=$ polished $)$

Tabelle 2. Prüfserie mit zylindrischen rotierenden Elektroden $(G=$ geschliffen, $P=$ poliert $)$

\begin{tabular}{|c|c|c|c|c|c|c|c|c|}
\hline $\begin{array}{l}\text { Series } \\
\text { number }\end{array}$ & $\begin{array}{l}\text { Position } \\
1 \\
\text { Material }\end{array}$ & 2 & 3 & 4 & 5 & 6 & $\begin{array}{l}\text { Exposure } \\
\text { temperature } \\
{ }^{\circ} \mathrm{C}\end{array}$ & Pre-treatment \\
\hline I & - & - & $1.36 \mathrm{~L}$ & $1.36 \mathrm{~L}$ & $1.51 \mathrm{~L}$ & $1.51 \mathrm{~L}$ & 20 & G \\
\hline II & - & - & $1.36 \mathrm{~L}$ & $1.36 \mathrm{~L}$ & $1.51 \mathrm{~L}$ & $1.51 \mathrm{~L}$ & 20 & $\mathrm{G}$ \\
\hline III & - & - & $1.36 \mathrm{~L}$ & $1.36 \mathrm{~L}$ & $1.78 \mathrm{~L}$ & $1.78 \mathrm{~L}$ & 20 & $\mathrm{G}$ \\
\hline IV & - & - & $1.36 \mathrm{~L}$ & $1.78 \mathrm{~L}$ & $1.51 \mathrm{~L}$ & $1.2 \mathrm{~L}$ & 20 & $\mathrm{G}$ \\
\hline \multirow[t]{3}{*}{ V } & $1.36 \mathrm{~L}$ & $1.36 \mathrm{~L}$ & & & & & 30 & G \\
\hline & & & $1.36 \mathrm{~L}$ & $1.36 \mathrm{~L}$ & & & 20 & $\mathrm{G}$ \\
\hline & & & & & $1.36 \mathrm{~L}$ & $1.36 \mathrm{~L}$ & 10 & $\mathrm{G}$ \\
\hline \multirow{2}{*}{ VI } & $1.36 \mathrm{~L}$ & $1.36 \mathrm{~L}$ & & & & & 20 & $\mathrm{G}$ \\
\hline & & & $1.36 \mathrm{~L}$ & $1.36 \mathrm{~L}$ & $11.36 \mathrm{~L}$ & $1.36 \mathrm{~L}$ & 20 & $G+P$ \\
\hline VII & - & & $2.5 \mathrm{H}$ & $2 \mathrm{H}$ & $1.5 \mathrm{H}$ & $1.2 \mathrm{H}$ & 20 & $G+P$ \\
\hline VIII & $2 \mathrm{H}$ & $2.5 \mathrm{H}$ & $2 \mathrm{CP}$ & $2.5 \mathrm{CP}$ & $2 \mathrm{DP}$ & $2.5 \mathrm{DP}$ & 20 & $G+P$ \\
\hline IX & $1.2 \mathrm{CP}$ & $1.5 \mathrm{CP}$ & $2 \mathrm{CP}$ & $2.5 \mathrm{CP}$ & $2 \mathrm{DP}$ & $2.5 \mathrm{DP}$ & 30 & $G+P$ \\
\hline$X$ & $1.2 \mathrm{CP}$ & $1.5 \mathrm{CP}$ & $2 \mathrm{CP}$ & $2.5 \mathrm{CP}$ & $1.2 \mathrm{H}$ & $1.5 \mathrm{H}$ & 30 & $G+P$ \\
\hline $\mathrm{XI}$ & $1.2 \mathrm{H}$ & $1.5 \mathrm{H}$ & $2 \mathrm{H}$ & $2.5 \mathrm{H}$ & $2 \mathrm{H}$ & $2.5 \mathrm{H}$ & 30 & $G+P$ \\
\hline XII & $2 \mathrm{DP}$ & $2.5 \mathrm{DP}$ & $1.2 \mathrm{DP}$ & $1.5 \mathrm{DP}$ & $1.2 \mathrm{DP}$ & $1.5 \mathrm{DP}$ & 30 & $G+P$ \\
\hline XIII & $1.4 \mathrm{H}$ & 37 & 43 & 47 & - & - & 20 & $G+P$ \\
\hline $\mathrm{XIV}$ & 37 & 47 & 48 & 50 & - & - & 20 & $G+P$ \\
\hline XV & $1.4 \mathrm{H}$ & 43 & 48 & 50 & - & - & 20 & $G+P$ \\
\hline
\end{tabular}


Table 3. $\mathrm{k}$-Values for commercial CuNi $10 \mathrm{Fe}$ alloys at various positions of the cross sectioned tubes

Tabelle 3. k-Werte für handelsübliches $\mathrm{CuNi} 10 \mathrm{Fe}$ an verschiedenen Stellen der Rohrquerschnitte

\begin{tabular}{|c|c|c|c|c|c|c|c|c|c|c|c|c|c|c|c|c|}
\hline & \multicolumn{3}{|c|}{ CuNi $10 \mathrm{Fe} 1.20$} & \multicolumn{5}{|c|}{ CuNi $10 \mathrm{Fe} 1.36$} & \multicolumn{3}{|c|}{ CuNi $10 \mathrm{Fe} 1.51$} & & \multicolumn{4}{|c|}{ CuNi $10 \mathrm{Fe} 1.78$} \\
\hline & $\mathrm{k}_{\mathrm{Fe}}$ & $\mathrm{k}_{\mathrm{Cu}}$ & $\mathbf{k}_{\mathrm{Ni}}$ & $\frac{\Sigma \mathrm{k}_{\mathrm{i}}}{\mathrm{i}}$ & $\mathbf{k}_{\mathrm{Fe}}$ & $\mathrm{k}_{\mathrm{Cu}}$ & $\mathrm{k}_{\mathrm{Ni}}$ & $\frac{\Sigma \mathbf{k}_{\mathbf{i}}}{\mathrm{i}}$ & $\mathbf{k}_{\mathrm{Fe}}$ & $\mathrm{k}_{\mathrm{Cu}}$ & $\mathrm{k}_{\mathrm{Ni}}$ & $\frac{\Sigma \mathbf{k}_{\mathbf{i}}}{\mathrm{i}}$ & $\mathrm{k}_{\mathrm{Fe}}$ & $\mathrm{k}_{\mathrm{Cu}}$ & $\mathrm{k}_{\mathrm{Ni}}$ & $\frac{\Sigma \mathrm{k}_{\mathrm{i}}}{\mathrm{i}}$ \\
\hline Outside & 0.74 & 0.98 & 0.85 & 0.86 & 0.70 & 0.92 & 0.80 & 0.81 & 0.70 & 0.92 & 0.83 & 0.82 & 0.80 & 0.95 & 0.93 & 0.89 \\
\hline Centre & 0.79 & 0.95 & 0.88 & 0.87 & 0.41 & 0.90 & 0.57 & 0.63 & 0.87 & 0.97 & 0.93 & 0.92 & 0.75 & 0.95 & 0.86 & 0.85 \\
\hline Inside & 0.74 & 0.93 & 0.83 & 0.83 & 0.61 & 0.90 & 0.68 & 0.73 & 0.62 & 0.93 & 0.73 & 0.76 & 0.71 & 0.91 & 0.87 & 0.80 \\
\hline
\end{tabular}

lization had taken place. Extrusion resulted in the same type of segregation structure as found for the commercial CuNi 10 Fe alloys (Fig. 5). The corresponding $\mathrm{k}$-values, given in Table 4, indicate a pronounced segregation.

In order to investigate the corrosion behaviour of these alloys homogeneous material is required. As the appropriate homogenizing conditions are not known, samples were heated during $1 \mathrm{~h}$ at 900,950 and $1000{ }^{\circ} \mathrm{C}$ in a reducing gas atmosphere, followed by water quenching. From the k-values (Table 4) it can be concluded that the outer side of the tube sample is completely homogeneous after $1 \mathrm{~h}$ heating at $1000^{\circ} \mathrm{C}$. There-

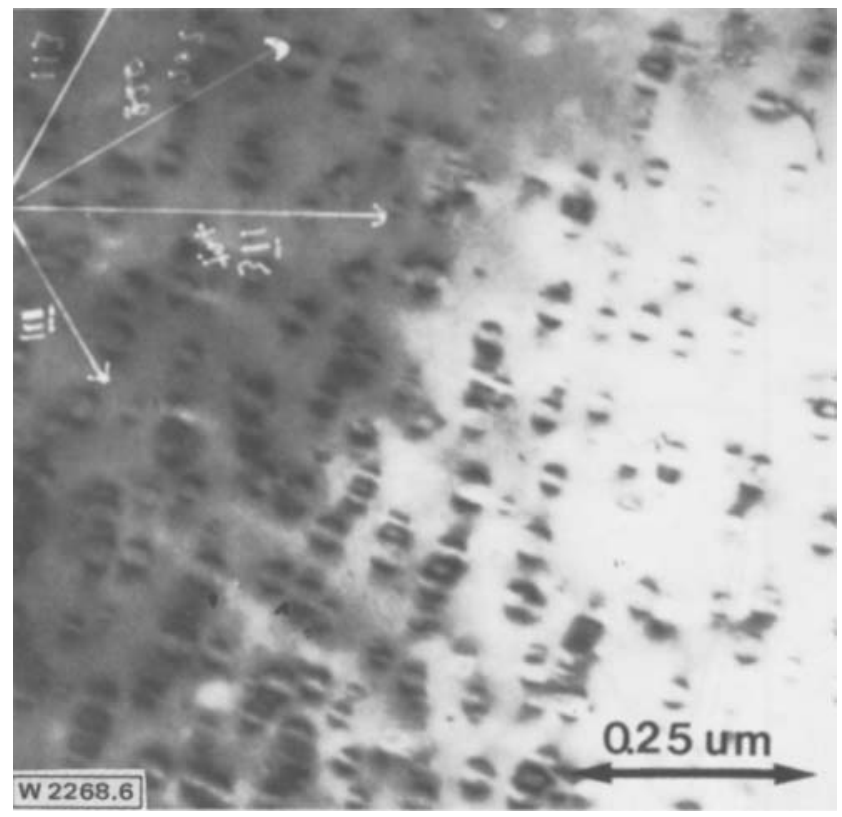

Fig. 6. TEM-image of strain fields indicating coherent precipitates in $\mathrm{CuNi} 10 \mathrm{Fe} 2.5\left(1000^{\circ} \mathrm{C} 4 \mathrm{~h} / \mathrm{WQ} / 600^{\circ} \mathrm{C} 92 \mathrm{~h}\right) ; 96,000: 1$

Abb. 6. TEM-Bild der Dehnungsfelder mit kohärenten Ausscheidungen in $\mathrm{CuNi} 10 \mathrm{Fe} 2,5\left(100^{\circ} \mathrm{C} 4 \mathrm{~h} / \mathrm{W} / 600^{\circ} \mathrm{C} 92 \mathrm{~h}\right) ; 96000: 1$ fore, a heat treatment of $4 \mathrm{~h}$ at $1000^{\circ} \mathrm{C}$ was chosen in order to assure a complete homogeneity for the inner side as well.

Pronounced heat treatment of the homogenized alloys at 600 or $650^{\circ} \mathrm{C}$ causes continuous precipitation and increases the hardness and the magnetic permeability [5]. Heating times exceeding $100 \mathrm{~h}$ were necessary to achieve precipitates that were visible in the transmission electron microscope. The preceeding stage of coherent precipitates is illustrated in Fig. 6.

The precipitates are enriched in nickel $(30 \%)$ and iron $(17 \%)$ and depleted in copper $(53 \%)$ as was determined by electron microprobe analysis for a grain boundary precipitate. It should be noted that the size was about $1 \mu \mathrm{m}$ which is about the diameter of the electron beam. The analysis of the precipitate agrees well with the results obtained by Berg and De Lange [14].

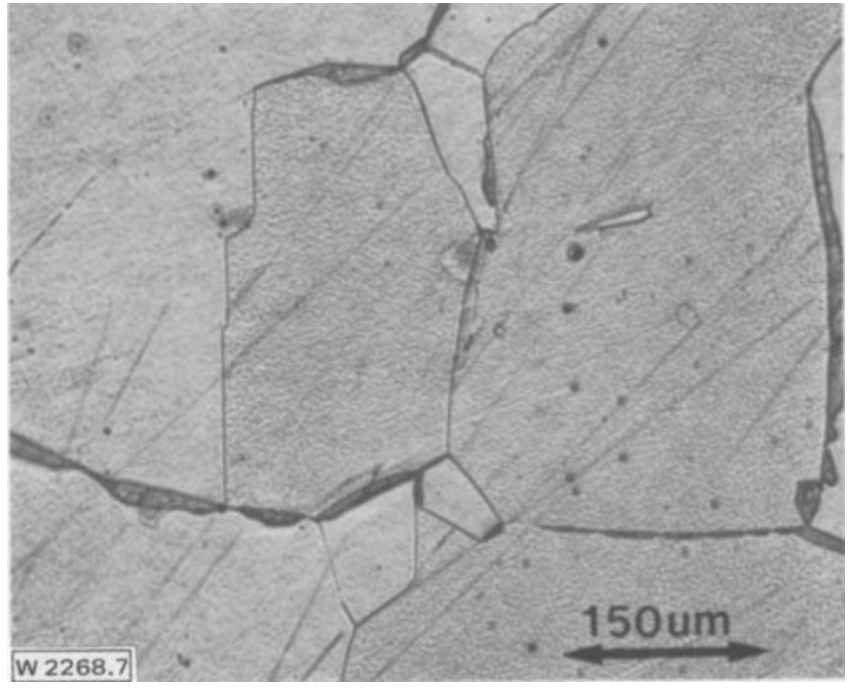

Fig. 7. Optical micrographs of discontinuous grain boundary precipitates in CuNi 10 Fe $2.5\left(1000{ }^{\circ} \mathrm{C} 4 \mathrm{~h} / \mathrm{WQ} / 450^{\circ} \mathrm{C} 102 \mathrm{~h}\right) ; 140: 1$

Abb. 7. Mikrofotos der diskontinuierlichen Korngrenzenausscheidungen in $\mathrm{CuNi} 10 \mathrm{Fe} 2,5\left(1000^{\circ} \mathrm{C} 4 \mathrm{~h} / \mathrm{W} / 450^{\circ} \mathrm{C} 102 \mathrm{~h}\right) ; 140: 1$

Table 4. $\mathrm{k}$-Values for pure $\mathrm{CuNi} 10 \mathrm{Fe} 1.5$, after extrusion and after subsequent 1 hour anneal at 900.950 and $1000^{\circ} \mathrm{C}$

Tabelle 4. k-Werte für reines CuNi $10 \mathrm{Fe} 1.5$ nach Strangpressen und einstündigem Glühen bei 900$)$, 950 ) und $10000^{\circ} \mathrm{C}$

\begin{tabular}{|c|c|c|c|c|c|c|c|c|c|c|c|c|c|c|c|c|}
\hline & \multicolumn{3}{|c|}{$\begin{array}{l}\mathrm{CuNi} 10 \mathrm{Fe} 1.5 \\
\text { as delivered }\end{array}$} & \multirow[b]{2}{*}{$\frac{\Sigma \mathrm{k}_{\mathrm{i}}}{\mathrm{i}}$} & \multicolumn{4}{|c|}{1 hour $900^{\circ} \mathrm{C}$} & \multicolumn{3}{|c|}{1 hour $950^{\circ} \mathrm{C}$} & \multicolumn{5}{|c|}{1 hour $1000^{\circ} \mathrm{C}$} \\
\hline & $\mathbf{k}_{\mathrm{Fe}}$ & $\mathrm{k}_{\mathrm{Cu}}$ & $\mathbf{k}_{\mathrm{Ni}}$ & & $\mathrm{k}_{\mathrm{Fe}}$ & $\mathbf{k}_{\mathrm{Cu}}$ & $\mathrm{k}_{\mathrm{Ni}}$ & $\frac{\Sigma \mathrm{k}_{\mathrm{i}}}{\mathrm{i}}$ & $\mathrm{k}_{\mathrm{Fe}}$ & $\mathrm{k}_{\mathrm{Cu}}$ & $\mathrm{k}_{\mathrm{Ni}}$ & $\frac{\Sigma \mathrm{k}_{\mathrm{i}}}{\mathrm{i}}$ & $\mathrm{k}_{\mathrm{Ft}}$ & $\mathrm{k}_{\mathrm{Cu}}$ & $\mathrm{k}_{\mathrm{Ni}}$ & $\frac{\Sigma \mathbf{k}_{\mathrm{i}}}{\mathrm{i}}$ \\
\hline Outside & - & - & - & - & - & - & - & - & 0.97 & 0.99 & 0.97 & 0.97 & 1.00 & 1.00 & 1.00 & 1.00 \\
\hline Centre & 0.63 & 0.95 & 0.74 & 0.77 & 0.90 & 0.97 & 0.95 & 0.94 & 0.95 & 1.00 & 0.97 & 0.97 & 0.93 & 0.99 & 0.94 & 0.95 \\
\hline Inside & - & - & - & - & - & - & - & - & 0.92 & 0.99 & 0.95 & 0.95 & 0.87 & 0.99 & 0.96 & 0.94 \\
\hline
\end{tabular}




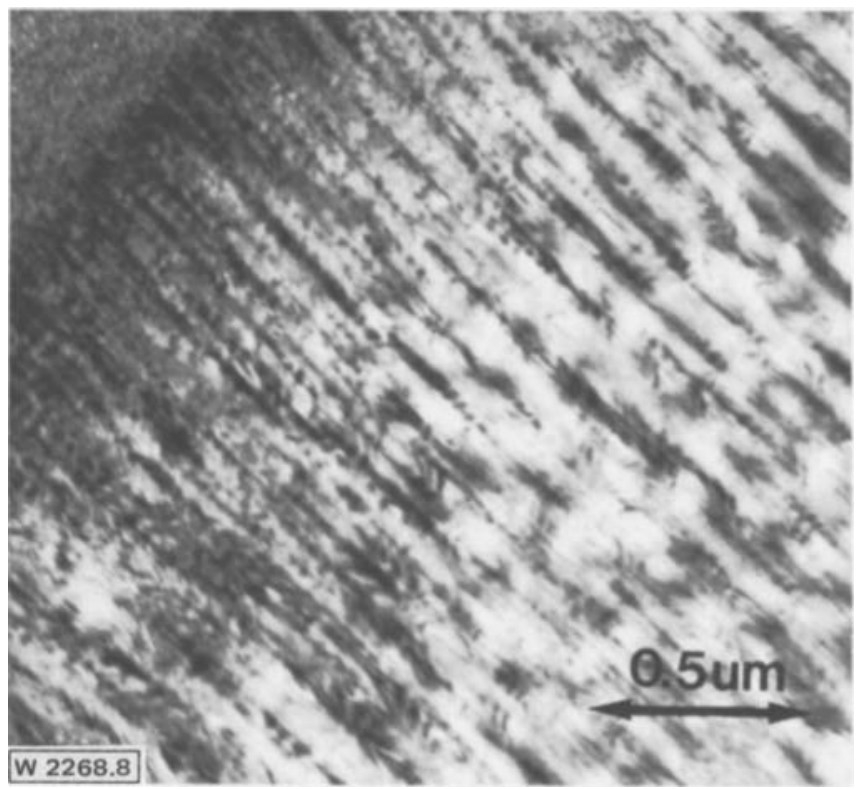

Fig. 8. TEM-image of discontinuous precipitates in $\mathrm{CuNi} 10 \mathrm{Fe} 2.5$ $\left(1000{ }^{\circ} \mathrm{C} 4 \mathrm{~h} / \mathrm{WQ} / 450{ }^{\circ} \mathrm{C} 102 \mathrm{~h}\right) ; 44,400: 1$

Abb. 8. TEM-Bild der diskontinuierlichen Ausscheidungen in CuNi 10 Fe 2,5 $\left(1000{ }^{\circ} \mathrm{C} 4 \mathrm{~h} / \mathrm{W} / 450^{\circ} \mathrm{C} 102 \mathrm{~h}\right) ; 44400: 1$

Heating the homogenized material at $450^{\circ} \mathrm{C}$ causes the formation of discontinuous precipitates at the grain boundaries. In Fig. 7 this is shown for CuNi $10 \mathrm{Fe} 2.5\left(450^{\circ} \mathrm{C} 102 \mathrm{~h}\right)$. Fig. 8 shows these precipitates in the transmission electron microscope. A two phase lamellar structure is clearly visible. The lamellae are too narrow to be analysed by X-ray diffraction or electron microprobe analysis. According to expectations the average composition of the area with discontinuous precipitation turned out to be comparable with the nominal composites of the alloy. It should be noted that the pronounced heat treatment at $450{ }^{\circ} \mathrm{C}$, resulting in discontinuous precipitates, does not occur in practice.

\subsection{Corrosion experiments}

\subsubsection{Cylindrical electrodes}

\subsubsection{Commercial CuNi $10 \mathrm{Fe}$ alloys}

As regards the course of the free corrosion potential of these alloys in the as delivered state two cases can be distinguished. Either the corrosion potential remains more or less constant during the exposure period, or the potential changes in noble direction after some time, from about $-240 \mathrm{mV}$ to $-80 \mathrm{mV}$ vs SCE. In Fig. 9 representative examples are given. The occurrence of the potential jump is not predictable: under exactly the same conditions the same material shows both features. Moreover, the potential jump is found to be independent on the iron content.

The course of the reciprocal polarisation resistance in time also shows a definite distinction. Generally a rather sharp decrease of $R_{\mathrm{P}}^{-1}$ down to a steady state value is found. However, the time of exposure this decrease occurs as well as the steady state value of $R_{\mathrm{P}}^{-1}$ - being a measure of the steady state corrosion rate - also show rather large differences, notwithstanding the equal test conditions.
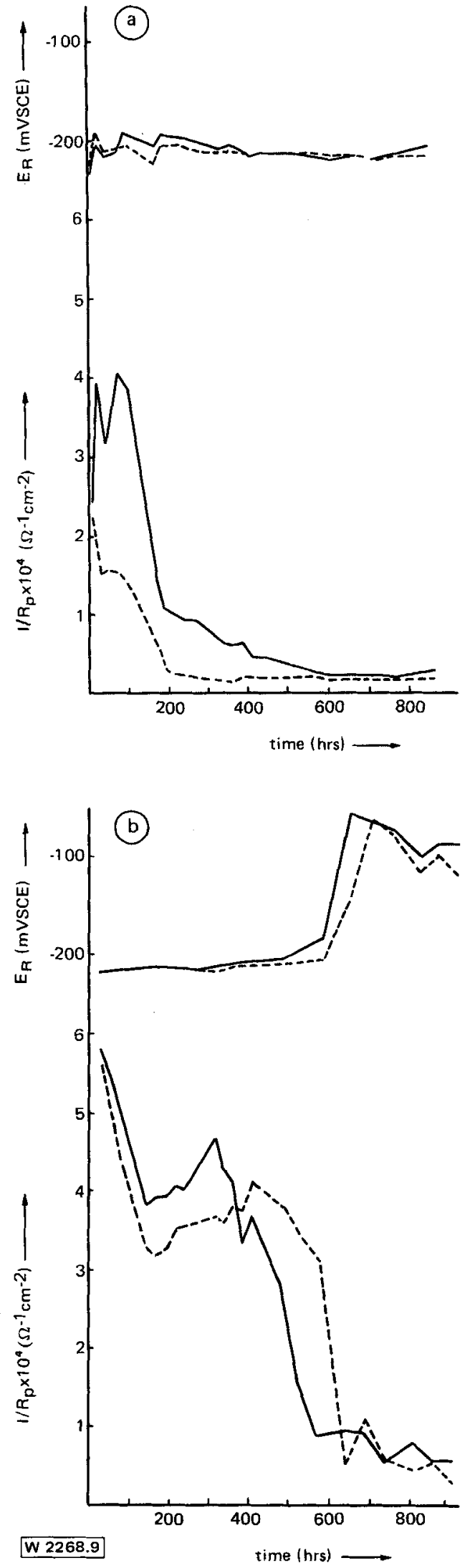

Fig. 9. Corrosion potential $\left(E_{\mathrm{r}}\right)$ and reciprocal value of polarisation resistance $\left(1 / R_{p}\right)$ as a function of time for CuNi $10 \mathrm{Fe} 1.78$ (a) and CuNi 10 Fe 1.36 (b)

Abb. 9. Korrosionspotential $\left(E_{r}\right)$ und reziproker Wert des Polarisationswiderstandes $\left(1 / R_{p}\right)$ in Abhängigkeit von der Zeit für CuNi 10Fe 1,78 (a) und CuNi 10 Fe 1,36 (b) 
Table 5. $\mathrm{R}_{\mathrm{P}}^{-1}$-values $\left(\Omega^{-1} \mathrm{~cm}^{-2} \times 10^{4}\right)$ after $900 \mathrm{~h}$ exposure of commercial alloys at $20^{\circ} \mathrm{C}$,

Tabelle 5. Werte von $1 / \mathrm{R}_{\mathrm{p}}\left(\mathrm{Ohm}^{-1} \mathrm{~cm}^{-2} \cdot 10^{4}\right)$ nach $900 \mathrm{~h}$ Korrosion für handelsübliche Legierungen bei $20^{\circ} \mathrm{C}$

\begin{tabular}{ccccccc} 
CuNi 10Fe 1.2 & \multicolumn{2}{l}{$\begin{array}{l}\text { CuNi 10Fe 1.36 } \\
\text { Potential jump }\end{array}$ CuNi 10Fe 1.51 } & \multicolumn{2}{l}{ CuNi 10Fe 1.78 } \\
yes no & yes & no & yes & no & yes & no \\
\hline \multirow{2}{*}{0.22} & 0.86 & 0.19 & 0.68 & 0.4 & 0.86 & 0.3 \\
& 0.14 & 0.40 & 0.62 & & & 0.13 \\
& 0.66 & 0.02 & & & & \\
& 0.31 & 0.19 & & & & \\
& 0.53 & 0.08 & & & & \\
& 0.62 & & & & & \\
& 0.32 & & & & \\
\hline
\end{tabular}

In those cases, where no potential jump is found, the decrease of $R_{P}^{-1}$ generally occurs after a relatively short exposure period. For the alloys showing a potential jump this generally coincides with a rather sharp decrease of $R_{p}^{-1}$. However, in the latter case the ultimate value of $R_{\mathrm{p}}^{-1}$ is generally higher, as, in spite of the rather large scatter, can be concluded from Table 5.
3.2.1.2 Pure CuNi 10 Fe alloys, containing 1.5, 2.0 and $2.5 \%$ $\mathrm{Fe}$ and commercial $\mathrm{CuNi} 10 \mathrm{Fe} 1.2$

These alloys were exposed in the three heat treated conditions described before, resulting in homogeneous material or precipitation structures, either continuous or discontinuous. As far as the homogenized material is concerned $\left(1000{ }^{\circ} \mathrm{C} 4 \mathrm{~h} /\right.$ WQ), none of the 14 samples showed a potential jump. Contrarily, material with discontinuous precipitates $\left(1000^{\circ} \mathrm{C} 4 \mathrm{~h} /\right.$ WQ $/ 450^{\circ} \mathrm{C} 100 \mathrm{~h}$ ) showed a potential jump from about -240 $\mathrm{mV}$ to $-80 \mathrm{mV}$ vs SCE. The potential jump coincides with a decrease of the $R_{p}^{-1}$ value. Following on the potential jump the corrosion potential sometimes fluctuated rather strongly. Also large fluctuations in the $R_{\mathrm{P}}^{-1}$ values were found which may be attributed to corrosion products flaking off. The corrosion potential of alloys with continuous precipitates $\left(1000^{\circ} \mathrm{C} 4 \mathrm{~h} /\right.$ $\mathrm{WQ} / 650^{\circ} \mathrm{C} 10^{\prime}$ ) remain rather constant during exposure. Only for one out of ten specimens a potential jump was observed. Compared to the alloys containing discontinuous precipitates the homogeneous materials as well as the alloys with continuous precipitates show an early decrease in $R_{p}^{-1}$. In Table 6 the steady state $R_{\mathbf{p}}^{-1}$ values are given. It is clear that the values for the alloys with discontinuous precipitation are highest, also in comparison with the values of the commercial as delivered alloys (Table 5).

Table 6. $\mathrm{R}_{\mathrm{P}}^{-1}$-values $\left(\Omega^{-1} \mathrm{~cm}^{-2} \times 10^{4}\right)$ after $900 \mathrm{~h}$ exposure for various alloy compositions and microstructures (the underlined figures refer to a potential jump)

Tabelle 6. Werte von $1 / \mathrm{R}_{\mathrm{p}}\left(\mathrm{Ohm}^{-1} \mathrm{~cm}^{-2} \cdot 10^{4}\right)$ nach $900 \mathrm{~h}$ für verschiedene Legierungszusammensetzungen und Gefüge (die unterstrichenen Ziffern geben einen Potentialsprung an)

\begin{tabular}{|c|c|c|c|c|c|c|c|c|c|c|c|c|c|}
\hline \multirow{2}{*}{$\begin{array}{l}\text { Material } \\
\text { Micro- } \\
\text { structure }\end{array}$} & \multicolumn{3}{|c|}{ CuNi $10 \mathrm{Fe} 1.2$} & \multicolumn{3}{|c|}{$\mathrm{CuNi} 10 \mathrm{Fe} 1.5$} & \multicolumn{3}{|c|}{$\mathrm{CuNi} 10 \mathrm{Fe} 2.0$} & \multicolumn{3}{|c|}{ CuNi 10 Fe 2.5} & \multirow{2}{*}{$\begin{array}{l}\mathrm{T} \\
\left({ }^{\circ} \mathrm{C}\right)\end{array}$} \\
\hline & $\mathbf{H}$ & $\mathrm{CP}$ & $\mathrm{DP}$ & $\mathrm{H}$ & $\mathrm{CP}$ & $\mathrm{DP}$ & $\mathrm{H}$ & $\mathrm{CP}$ & $\mathrm{DP}$ & $\mathbf{H}$ & $\mathrm{CP}$ & $\mathrm{DP}$ & \\
\hline & 0.30 & & & 0.33 & & & $\begin{array}{l}0.38 \\
0.41\end{array}$ & 0.41 & $\underline{0.72}$ & $\begin{array}{l}0.54 \\
0.32\end{array}$ & $\underline{0.7}$ & $\underline{1.28}$ & 20 \\
\hline & 0.85 & 0.30 & 0.42 & 0.14 & 0.39 & $\underline{1.35}$ & 0.09 & 0.09 & $\underline{1.34}$ & 0.10 & 0.11 & $\underline{1.24}$ & 30 \\
\hline & 0.87 & 0.28 & 1.26 & 0.6 & 0.10 & $\overline{1.46}$ & 0.49 & 0.15 & $\overline{1.21}$ & 0.23 & 0.10 & $\overline{1.91}$ & \\
\hline
\end{tabular}

Table 7. Course of the potential and the $\mathrm{R}_{\mathrm{p}}^{-1}$-value after $900 \mathrm{~h}$ exposure for CuNi $5 \mathrm{Fe}$ alloys and $\mathrm{CuNi} 10 \mathrm{Fe} 1.4$

Tabelle 7. Verlauf von Potential und $1 / \mathbf{R}_{\mathrm{p}}$ nach $900 \mathrm{~h}$ Korrosion für $\mathrm{CuNi} 5 \mathrm{Fe}$ und CuNi $10 \mathrm{Fe} 1,4$

\begin{tabular}{|c|c|c|c|c|c|c|}
\hline $\begin{array}{l}\text { Material } \\
\text { code }\end{array}$ & $\begin{array}{l}\text { Starting } \\
\text { potential } \\
(\mathrm{m} \vee \mathrm{SCE})\end{array}$ & $\begin{array}{l}\text { Potential } \\
\text { after } 24 \mathrm{~h} \\
(\mathrm{~m} V \mathrm{SCE})\end{array}$ & $\begin{array}{l}\text { Potential } \\
\text { after } 900 \mathrm{~h} \\
(\mathrm{mV} \text { SCE) }\end{array}$ & $\begin{array}{l}\text { Exposure time (h) } \\
\text { potential jump } \\
\text { occurs }\end{array}$ & $\begin{array}{l}1 / \mathrm{R}_{\mathrm{p}}\left(\Omega^{-1} \mathrm{~cm}\right. \\
\text { after } 900 \mathrm{~h}\end{array}$ & average \\
\hline 37 & -272 & $\begin{array}{l}-259 \\
-254\end{array}$ & $\begin{array}{l}-196 \\
-68\end{array}$ & $\overline{350}$ & $\begin{array}{l}0.04 \\
0.15\end{array}$ & 0.10 \\
\hline 43 & -282 & $\begin{array}{l}-263 \\
-262\end{array}$ & $\begin{array}{l}-76 \\
-72\end{array}$ & $\begin{array}{l}500 \\
250\end{array}$ & $\begin{array}{l}0.05 \\
0.03\end{array}$ & 0.04 \\
\hline 47 & -276 & $\begin{array}{l}-233 \\
-264\end{array}$ & $\begin{array}{l}-60 \\
-80\end{array}$ & $\begin{array}{l}800 \\
750\end{array}$ & $\begin{array}{l}0.09 \\
0.15\end{array}$ & 0.12 \\
\hline 48 & -285 & $\begin{array}{l}-257 \\
-233\end{array}$ & $\begin{array}{l}-70 \\
-213\end{array}$ & $\begin{array}{l}300 \\
-\end{array}$ & $\begin{array}{l}0.16 \\
0.14\end{array}$ & 0.15 \\
\hline 50 & -276 & $\begin{array}{l}-238 \\
-260\end{array}$ & $\begin{array}{l}-201 \\
-60\end{array}$ & $\overline{200}$ & $\begin{array}{l}0.06 \\
0.05\end{array}$ & 0.06 \\
\hline CuNi $10 \mathrm{Fe} 1.4$ & -254 & $\begin{array}{l}-236 \\
-220\end{array}$ & $\begin{array}{l}-199 \\
-212\end{array}$ & - & $\begin{array}{l}0.25 \\
0.17\end{array}$ & 0.21 \\
\hline
\end{tabular}


3.2.1.3 Pure CuNi 5 Fe alloys and the reference alloy $\mathrm{CuNi} 10 \mathrm{Fe} 1.4$

The corrosion potentials of the $\mathrm{CuNi} 5 \mathrm{Fe}$ alloys change during the first period of the exposure a few tens of $\mathrm{mV}$ in noble direction. Thereafter, two cases can be distinguished: the free corrosion potential remains more or less constant during further exposure or the free corrosion potential changes further in noble direction up to about $-70 \mathrm{mV}$ vs SCE. For the reference alloy $\mathrm{CuNi} 10 \mathrm{Fe} 1.4$ no potential jump was observed. Table 7 shows the corrosion potentials at the start of the exposure and after $24 \mathrm{~h}$; also the free corrosion potentials and the reciprocal values of the polarisation resistance at the end of the exposure period are included, as well as the exposure time at which a potential jump in noble direction was observed.

The steady state reciprocal polarisation resistance of the reference alloy is higher than those of the $\mathrm{CuNi} 5 \mathrm{Fe}$ alloys, alloy $\mathrm{nr} 43$ showing the lowest value. Contrary to CuNi $10 \mathrm{Fe}$, for the $\mathrm{CuNi} 5 \mathrm{Fe}$ alloys no relation could be found between the occurrence of a potential jump and the ultimate $R_{\mathrm{P}}^{-1}$ values. However, the steady state $R_{\mathrm{p}}^{-1}$ values of the CuNi $5 \mathrm{Fe}$ alloys are lower than the values for the $\mathrm{CuNi} 10 \mathrm{Fe}$ alloys (cf. Table 6 and 7).

\subsubsection{Tube experiments}

Out of the 40 tubes of homogenized $\mathrm{CuNi} 10 \mathrm{Fe}$, containing $1.2,1.5,2.0$ and $2.5 \% \mathrm{Fe}$, only one sample shows a jump in the free corrosion potential from $-240 \mathrm{mV}$ to $-80 \mathrm{mV}$ vs SCE. The corrosion potential of the other samples either changes somewhat in active direction (up to about $-275 \mathrm{mV}$ ) or in noble direction (max. about $-170 \mathrm{mV}$ ).

The test samples of the alloys with continuous precipitates showed a potential jump in noble direction (up to about -80 $\mathrm{mV}$ vs SCE) more often: with $1.2 \% \mathrm{Fe}$ two cases out of ten, with $1.5 \%$ none, and with 2 and $2.5 \% \mathrm{Fe}$ in each case six out of ten. The other test samples showed the same behaviour as mentioned before: either a change to about $-275 \mathrm{mV}$ or to about $-190 \mathrm{mV}$ vs SCE. After the potential jump, in some cases rather strong potential fluctuations were observed, which may be explained by corrosion products flaking off.

With the $\mathbf{4 0}$ test samples of the alloys containing discontinuous precipitates in all cases a potential jump was observed. Also in these cases sometimes potential fluctuations were found after the jump.

In Fig. 10 the ranges of $\mathrm{R}_{\mathrm{P}}^{-1}$ values are given for the exposure period between 350 and $1350 \mathrm{~h}$. The strong influence of the microstructure and the iron content is obvious. In alloys with discontinuous precipitates the values are always high, irrespective of the Fe-content. When continuous precipitates are present, the $\mathrm{R}_{\mathrm{p}}^{-1}$ values are greatest with 2.0 and $2.5 \% \mathrm{Fe}$, especially when a potential jump has occurred. It should be noticed, however, that the latter material still shows a low corrosion rate of about $40 \mu \mathrm{m} / \mathrm{yr}$.

Having reached the steady state $(580 \mathrm{~h})$ one half of the exposed test pipes was removed. The remaining tubes were removed after $1350 \mathrm{~h}$. In Fig. 11 the time dependent weight loss per unit surface area is shown. Each measuring point represents the average of five test samples; moreover, the values of the maximum and minimum weight loss per unit surface area are indicated. The values calculated concern the tubes without corrosion products, that is after chemically cleaning. The slope of the graphs in the steady state period (i.c. the

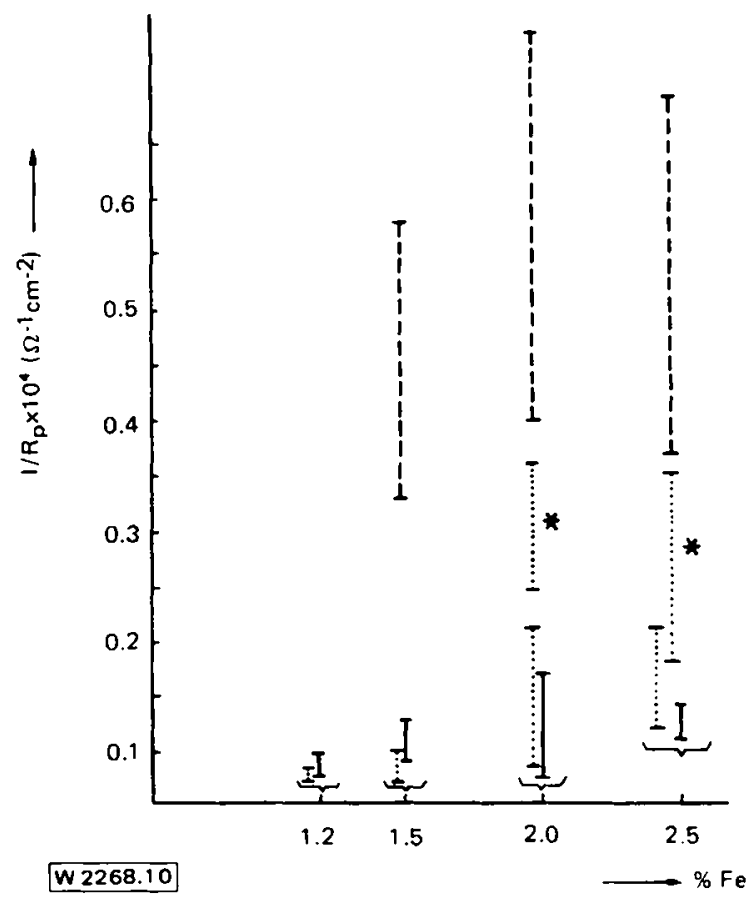

Fig. 10. Range of reciprocal values of the polarisation resistance $\left(1 / R_{p}\right)$ of $\mathrm{CuNi} 10 \mathrm{Fe}$ tube samples for various Fe-contents and microstructures between 320 and 1350 hrs exposure time $(--=$ homogeneous, $\ldots=$ continuous precipitation. ... ${ }^{*} \ldots=$ the same, for the cases where a potential jump was observed, $\cdots$ : = discontinuous precipitation)

Abb. 10. Bereich der reziproken Werte des Polarisationswiderstands $\left(1 / R_{p}\right)$ für rohrförmige Proben aus CuNi $10 \mathrm{Fe}$ mit verschiedenen Eisengehalten und Mikrogefügen bei Korrosionsdauern zwischen 320 und $1350 \mathrm{~h}$. (- homogen: ... kontinuierliche Ausscheidung;

dito. für die Fälle in denen ein Potentialsprung aultritt: - . . diskontinuierliche Ausscheidung)

steady state corrosion rate) is largest for the alloys containing discontinuous precipitates. In the alloys with continuous precipitation the weight losses are obviously highest for the 2.0 and $2.5 \% \mathrm{Fe}$ alloys.

In Fig. 12 the correlation between a potential jump and a more pronounced weight loss is shown for $\mathrm{CuNi} 10 \mathrm{Fe} 2$ with continuous precipitation.

In Fig. 13 the steady state corrosion rates are shown as a function of the Fe-content. Statistically, the steady state corrosion rate of the homogenized materials and the alloys containing continuous precipitates, do not differ significantly. Obviously for a given microstructure no influence of the Fe-content can be seen. However, the steady state corrosion rate of alloys containing discontinuous precipitates differ significantly from the homogenized alloys or alloys containing continuous precipitates, that is the steady state corrosion rate of $\mathrm{CuNi} 10 \mathrm{Fe}$ alloys is highest in case discontinuous precipitation has occurred.

\subsection{Investigation of the corrosion products}

\subsubsection{Cylindrical electrodes}

For the commercial CuNi $10 \mathrm{Fe}$ alloys two types of corrosion product layers can be distinguished. One type of layers is light to dark-brown coloured, frequently showing black bands in 

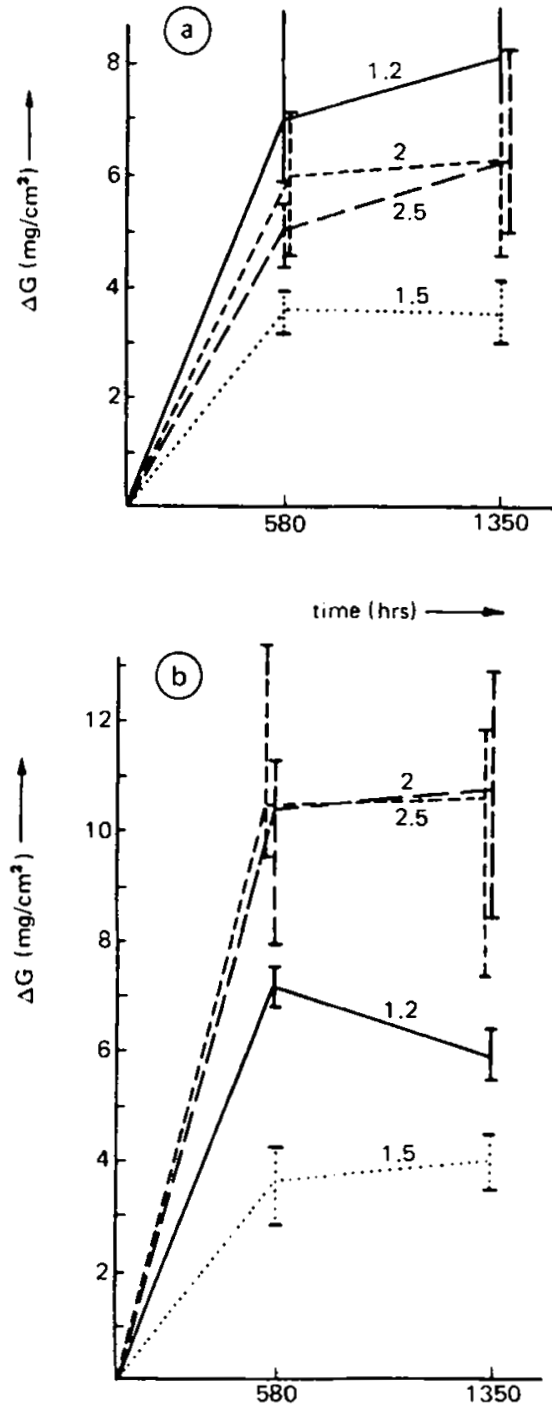

the direction of the rotation. These layers designated as type $A$, are relatively thin and adhere well to the base material. The second type of layer (type B) is grey to green-grey. These show a layered structure, as under the top layer a black layer is visible, under which a third, green layer. The green layer adheres reasonably well to the black layer. At the alloy surface in many cases red-orange coloured crystals, probably $\mathrm{Cu}_{2} \mathrm{O}$, can be observed. These $B$ type layers are thicker and adhere badly to the alloy surface, as compared with the earlier mentioned type $A$ layer. In Table 8 the characteristics of the two types are summarized.

Electron microprobe analysis of type B layers showed that the green parts contain much copper and chlorine, while the black layer shows a high iron concentration. In Fig. 14 X-ray images for $\mathrm{Cu}, \mathrm{Fe}, \mathrm{Ni}, \mathrm{Cl}$ and $\mathrm{O}$ for a type $\mathrm{B}$ layer are shown.

As the commercial CuNi $10 \mathrm{Fe}$ alloys in the as delivered state produce partly type A layers and partly type B layers, notwithstanding equal experimental conditions, it can be concluded that the corrosion behaviour of these alloys is not reproducible. On the contrary, the reproducibility of the corrosion behaviour of the precipitate free pure $\mathrm{CuNi} 10 \mathrm{Fe}$ alloys is much better. Similar experimental conditions give rise to similar corrosion products. The layers obtained are thin, goldbrown coloured, adhere well to the alloy surface and correspond more or less with the type A layers. Alloys, which con-

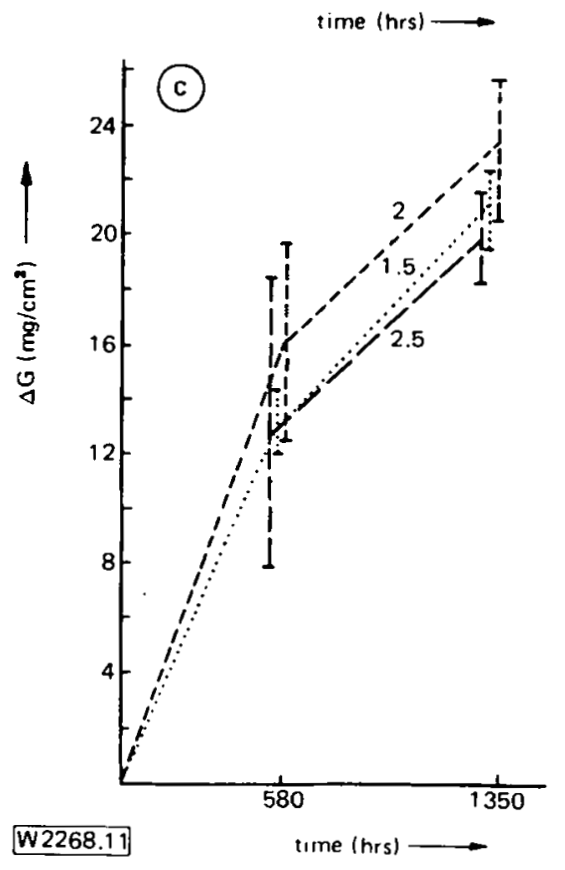

Fig. 11. Weight loss $(\Delta G)$ as a function of time and Fe-content for various microstructures, as determined for the chemically cleaned tube specimens: a) homogeneous, b) continuous precipitation, c) discontinuous precipitation

Abb. 11. Gewichtsverlust in Abhängigkeit von Zcit und Eisengehalt bei unterschiedlichen Mikrogefügen, ermittelt für chemisch gereinigte rohrförmige Proben, (a) homogen, (b) kontinuicrliche Ausscheidung,

(c) diskontinuierliche Ausscheidung

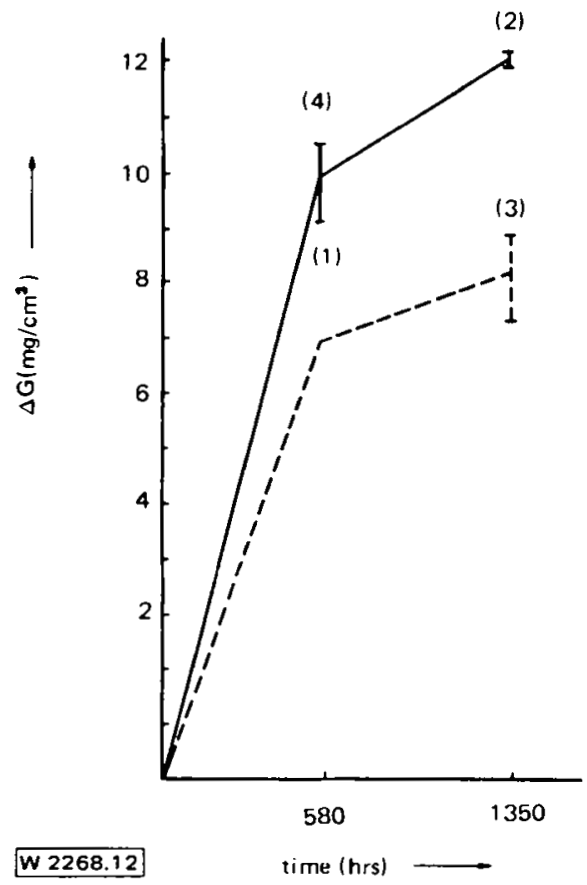

Fig. 12. Weight loss $(\Delta G)$ as a function of time for CuNi $10 \mathrm{Fe} 2$ containing continuous precipitates, with $(-)$ and without $(\cdots)$ a potential jump, as determined for the chemicallv cleaned specimens. The figures in parenthesis indicate the number of tubes involved

Abb. 12. Gewichtsverlust in Abhängigkeit von der Zeit für CuNi $10 \mathrm{Fe}$ mit kontinuierlichen Ausscheidungen mit $(-)$ und ohne (--) Potentialsprung, bestimmt für chemisch gercinigte Proben. Die Ziffern in Klammern geben die Zahl der betroffenen Rohre an. 


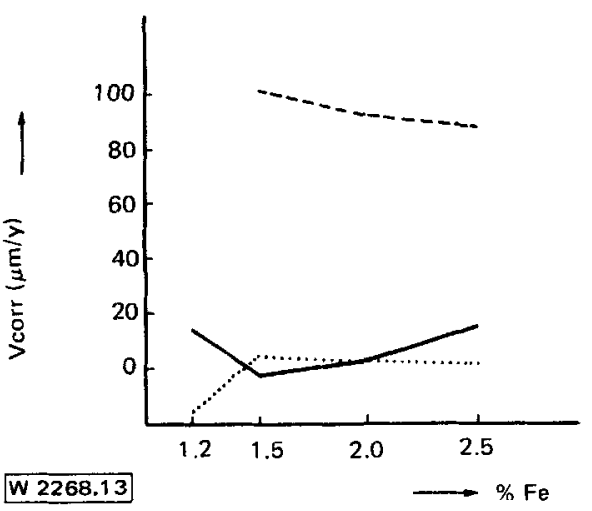

Fig. 13. Steady state corrosion rate $\left(\mathrm{V}_{\text {corr }}\right)$ as a function of Fe-content and microstructure. The corrosion rates have been calculated for the exposure period between 580 and 1350 hrs for chemically cleaned specimens: (-) homogeneous, (..) continuous precipitation and $(--)$ discontinuous precipitation

Abb. 13. Korrosionsgeschwindigkeit in stationärem Zustand in Abhängigkeit von Eisengehalt und Mikrogefüge; die Werte sind für Korrosionsdauern zwischen 580 und $1350 \mathrm{~h}$ und chemisch gereinigte Proben berechnet worden: (-) homogen, (..) kontinuierliche Ausscheidung und (---) diskontinuierliche Ausscheidung

tain continuous precipitates, form also thin layers. The colours of the layers depend on the Fe-content of the alloys: $1.2 \%$ brown $-1.5 \%$ predominantly brown $-2 \%$ and $2.5 \%$ black.

The alloys, which contain discontinous precipitates produce thick, black, nonadhering and often flaking-off corrosion products. The Fe-content does not seem to influence the type of layer in this case. These layers are not structured and correspond with the black sublayers, as found with the type $B$ layers of the commercial alloys. Underneath the layers locally red-orange coloured crystals have been observed, which seem to indicate the presence of $\mathrm{Cu}_{2} \mathrm{O}$.

The thickness of the layers produced on $\mathrm{CuNi} 10 \mathrm{Fe} 1.5$ and CuNi $10 \mathrm{Fe} 2.5$ after $920 \mathrm{~h}$ exposure under identical conditions are given in Table 9.

Table 8. Characteristics of the layers on commercial alloys

Tabelle 8. Eigenschaften der Schichten auf handelsüblichen Legierungen

\begin{tabular}{lll}
\hline & type A-layer & type B-layer \\
\hline Colour (outside $\rightarrow$ inside)light- to dark-brown & green/grey-black \\
& sometimes black bands & green-red/orange \\
Thickness $(\mu \mathrm{m})$ & $1-5 \mu \mathrm{m}$ & $\rightarrow 18 \mu \mathrm{m}$ \\
$\begin{array}{l}\text { Structure } \\
\text { Adherence }\end{array}$ & single layer & layered \\
& good & bad \\
\hline
\end{tabular}

Table 9. Thickness of corrosion product layers as found on $\mathrm{CuNi} 10 \mathrm{Fe} 1.5$ and $\mathrm{CuNi} 10 \mathrm{Fe} 2.5$ after $920 \mathrm{~h}$ exposure in seawater of $30{ }^{\circ} \mathrm{C}$

Tabelle 9. Dicke der Korrosionsproduktschichten auf CuNi $10 \mathrm{Fe} 1,5$ und $\mathrm{CuNi} 10 \mathrm{Fe} 2,5$ nach $920 \mathrm{~h}$ in Meerwasser bei $30{ }^{\circ} \mathrm{C}$

\begin{tabular}{lrc}
\hline & CuNi 10Fe 1.5 & CuNi 10 Fe 2.5 \\
\hline Homogeneous & $1-3.5 \mu \mathrm{m}$ & $3-7 \mu \mathrm{m}$ \\
Continuous precipitation & $1.5-5 \mu \mathrm{m}$ & $3-7 \mu \mathrm{m}$ \\
Discontinuous precipitation & $11-19 \mu \mathrm{m}$ & $17-24 \mu \mathrm{m}$ \\
\hline
\end{tabular}

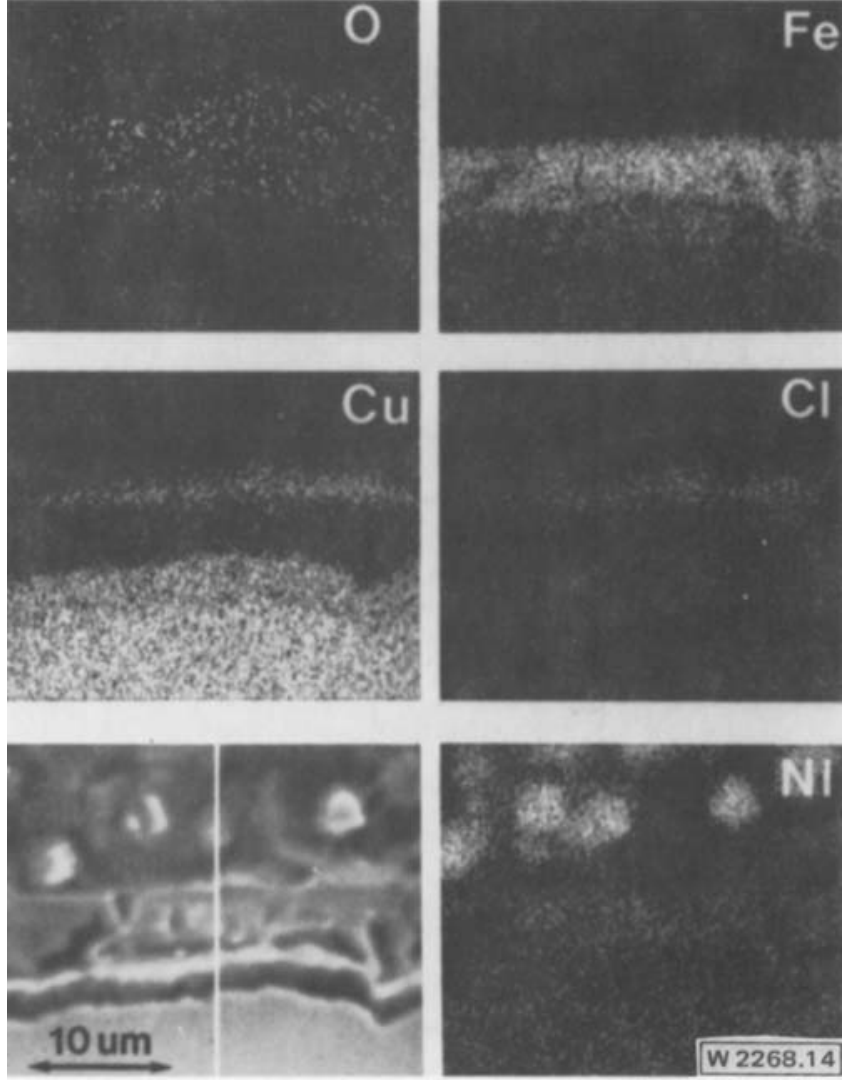

Fig. 14. Electron-image and $\mathrm{X}$-ray images for $\mathrm{Cu}, \mathrm{O}, \mathrm{Ni}, \mathrm{Cl}$ and $\mathrm{Fe}$ of a B-type layer (commercial CuNi 10 Fe 1.51). From bottom to top: alloy - corrosion product layer - embedding resin

Abb. 14. Elektronen- und Röntgenbilder für $\mathrm{Cu}, \mathrm{O}, \mathrm{Ni}, \mathrm{Cl}$ und $\mathrm{Fe}$ für eine Schicht vom B-Typ (handelsübliches CuNi 10 Fe 1.51). Von unten nach oben: Legierung - Korrosionsproduktschicht - Bettungsharz

In Fig. 15 and 16 the X-ray images of the corrosion products formed on homogeneous alloys and material with discontinuous precipitates respectively are given for $\mathrm{Cu}, \mathrm{Ni}, \mathrm{Fe}$ and $\mathrm{Cl}$. In both cases the layers are enriched in iron and nickel, as compared with the matrix. For the black layer (Fig. 16) the iron enrichment is greatest.

The colour of the corrosion products formed on $\mathrm{CuNi} 5 \mathrm{Fe}$ alloys varies from black to brown. Alloy number 37, 43 and 50 show black corrosion products in contrast to numbers 47 and 48 , which are brown. On the reference alloy CuNi 10 Fe 1.4 a gold-brown corrosion product layer was formed.

\subsubsection{Tube samples}

The corrosion products, which are formed on homogeneous alloys are always brown, irrespective of the Fe-content. On alloys, containing discontinuous precipitates always brownblack layers were observed. In case of continuous precipitation the colour depends on the Fe-content: $1.2 \%$ brown, $1.5 \%$, $2.0 \%$ and $2.5 \%$ brown-black. On all layers locally green corrosion products are found. In the direction of the seawater flow a kind of striation was observed.

In the corrosion products, formed on alloys with discontinuous precipitates small pores could be observed. Also, locally the layers flaked off, showing red-orange coloured material underneath. The same phenomenon was found with alloys 

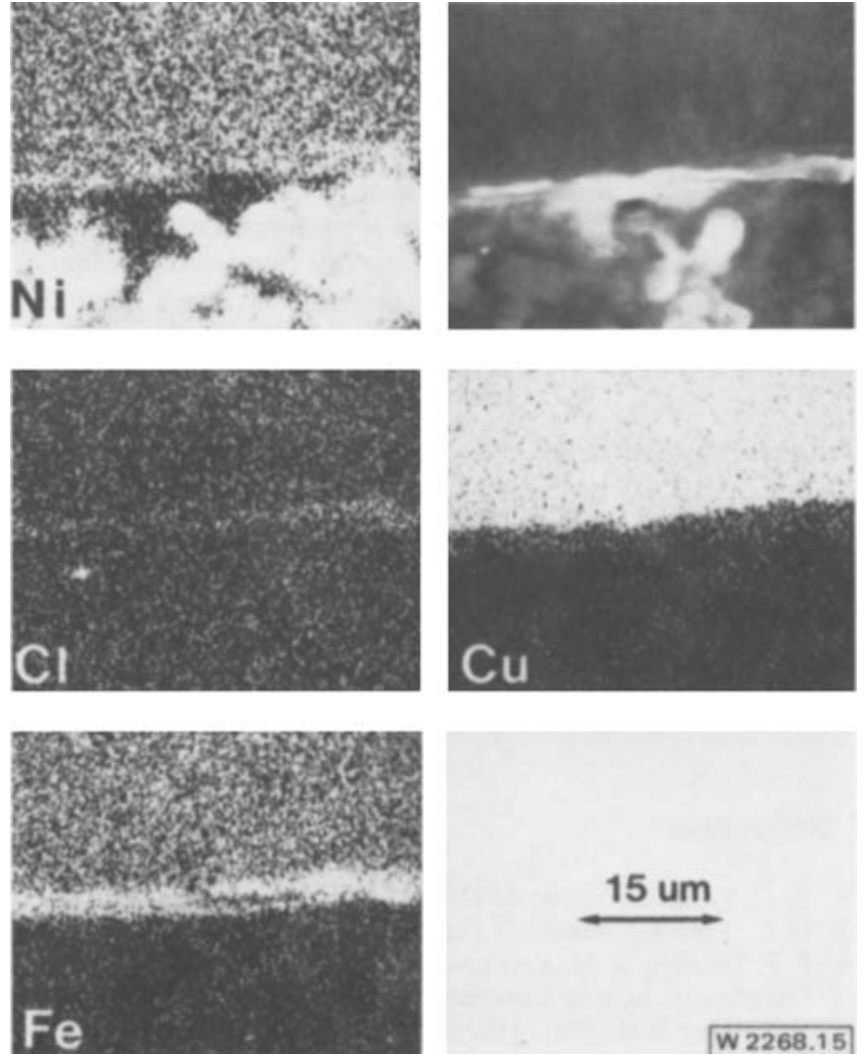

Fig. 15. Electron-image and $\mathrm{X}$-ray images for $\mathrm{Cu}, \mathrm{Ni}, \mathrm{Cl}$ and $\mathrm{Fe}$ in the corrosion layer of homogeneous $\mathrm{CuNi} 10 \mathrm{Fe} 2$. From top to bottom: alloy - corrosion product layer - embedding resin

Abb. 15. Elektronen- und Röntgenbilder für $\mathrm{Cu}, \mathrm{Ni}, \mathrm{Cl}$ und $\mathrm{Fe}$ in der Korrosionsschicht von homogenem $\mathrm{CuNi} 10 \mathrm{Fe} 2$. Von oben nach unten: Legierung - Korrosionsproduktschicht - Bettungsharz

containing continuous precipitates, provided the Fe-content was 2.0 or $2.5 \%$ and the corrosion potential had jumped in noble direction.

\section{Discussion}

In literature the occurrence of potential jumps in noble direction during seawater exposure has been noticed by various authors. Macdonald et al observed a potential jump for $\mathrm{CuNi} 10 \mathrm{Fe} 1.34$ in oxygen saturated natural seawater but no jump in airsaturated seawater [15]. Syrett et al [16] observed potential jumps for $\mathrm{CuNi} 10 \mathrm{Fe}$ as well as for $\mathrm{CuNi} 30 \mathrm{Fe}$ in aerated seawater. Stewart and La Que [7] and Efird [11] found the free corrosion potential to remain more or less constant at -200 to $-250 \mathrm{mV}$, independent on microstructure or $\mathrm{Fe}$ content up to $3.5 \%$.

From our experiments a definite influence on $\mathrm{Fe}$-content and microstructure for laboratory manufactured alloys could be determined. That is to say, one-phase homogeneous alloys show no potential jump irrespective of the Fe-content between 1.2 and $2.5 \%$, whereas two phase alloys containing discontinuous precipitates show a potential jump for Fe-contents between 1.2 and $2.5 \%$. Alloys with continuous precipitates take an in-between position in the sense that for low Fe-content $(1.2$ and $1.5 \%)$ usually no potential jump takes place whereas for higher Fe-content ( 2 and $2.5 \%$ ) predominantly a potential jump is observed.
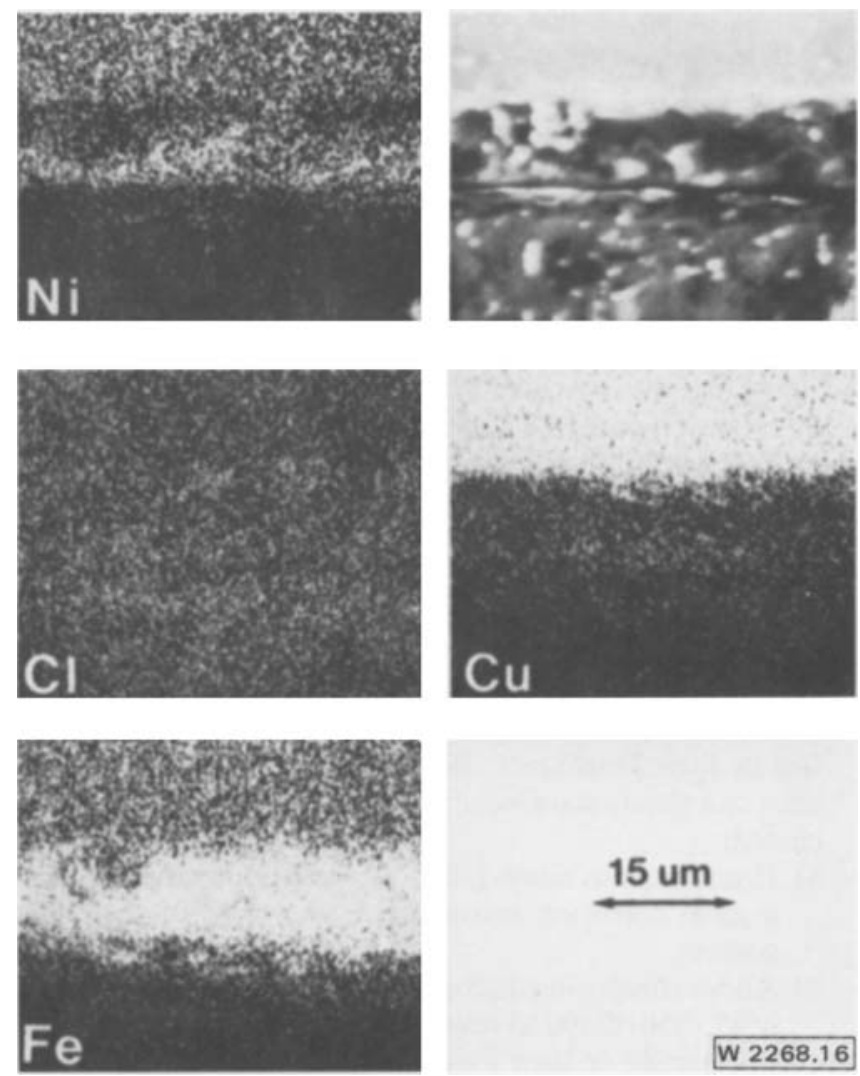

Fig. 16. Electron image and $\mathrm{X}$-ray images for $\mathrm{Cu}, \mathrm{Ni}, \mathrm{Cl}$ and $\mathrm{Fe}$ in the corrosion layer of $\mathrm{CuNi} 10 \mathrm{Fe} 2.5$ containing discontinuous precipitates; see further Fig. 15

Abb. 16. Elektronen- und Röntgenbilder für $\mathrm{Cu}, \mathrm{Ni}, \mathrm{Cl}$ und $\mathrm{Fe}$ in der Korrosionsschicht von $\mathrm{CuNi} 10 \mathrm{Fe} 2,5$ mit diskontinuierlichen Ausscheidungen; sonst siehe Abb. 15

Unlike the above mentioned well defined alloys the commercial alloys did show a different behaviour with respect to potential jump and appearance of the corrosion products. That is to say, pieces from the same tube show either a potential jump or not under identical exposure conditions. As for these materials a definite segregation has been observed, the irreproducible behaviour may be due to the incidental composition at the surface. It should be noted, however, that no direct evidence for the presence of precipitates in the segregation bands was obtained. Besides, in view of the fact that discontinuous precipitates can only be produced by prolonged heat treatments $\left(450{ }^{\circ} \mathrm{C} 100 \mathrm{~h}\right)$ which do not occur during fabrication or application, commercial alloys will not contain discontinuous precipitates. At most precipitates with a continuous nature may be expected. Attention will be paid to this particular point in the continuation of our work.

The same holds for the explanation of the presence or absence of a potential jump. In particular as from this work it turned out that the mere presence or absence of such a jump is related to the corrosion behaviour. Referring to the reciprocal polarisation resistance it has been proved that a relatively high $\mathbf{R}_{\mathbf{P}}^{-1}$ value, and hence a relatively high corrosion rate, corresponds to the appearance of a potential jump and the reverse. The same holds for the weight loss: a relatively high weight loss reflects the situation of a potential jump and the reverse.

Also for the steady state corrosion rate, determined from weight loss as a function of time, it is clear that the highest steady state corrosion rate occurs for the material which shows 
a potential jump. A final observation in connection with the potential jump concerns the features of the corrosion products. Thin, mainly brown coloured and good adhering corrosion layers are found for the materiais which show no potential jump and a good corrosion resistance. The alloys whith poor corrosion resistance correspond with black, thick and badly adhering corrosion layers. Such layers are found for alloys containing discontinuous precipitates.

The main problem to be solved is the explanation for the relationship between the microstructure and Fe-content on the one hand and the corrosion features as corrosion rate, course of the corrosion potential and corrosion products on the other hand. This will be investigated further, in particular by studying the detailed features of the corrosion products.

\section{Conclusions}

1. The general corrosion behaviour of CuNi 10 Fe alloys, with $1.2-2.5 \% \mathrm{Fe}$, is mainly governed by the microstructure and less by their Fe-content. Based on the polarisation resistance and steady state weight loss the following can be concluded:

a) Homogeneous alloys $\left(1000^{\circ} \mathrm{C} 4 \mathrm{~h} / \mathrm{WQ}\right)$ invariably show a good corrosion resistance, irrespective of their Fecontent.

b) Alloys comprising discontinuous precipitates $\left(1000^{\circ} \mathrm{C} 4\right.$ $\mathrm{h} / \mathrm{WQ} / 450^{\circ} \mathrm{C} 100 \mathrm{~h}$ ) reveal a lower corrosion resistance, irrespective of their Fe-content.

c) Alloys comprising continuous precipitates $\left(1000^{\circ} \mathrm{C} 4 \mathrm{~h} /\right.$ $\mathrm{WQ} / 650^{\circ} \mathrm{C} 10^{\prime}$ ) take an in-between position. Corrosion rates similar to the homogeneous alloys are mainly shown by the low Fe-containing alloys ( $\leqslant 1.5 \% \mathrm{Fe}$ ). Corrosion rates between those of the homogeneous and discontinuous precipitated material, are mainly shown by the alloys containing at least $2 \% \mathrm{Fe}$.

2. The difference in corrosion resistance is reflected in the absence or presence of a potential jump in noble direction, the former referring to the better corrosion resistance.

3. The corrosion behaviour is reflected in the morphology and appearance of the corrosion layer. Corrosion resistant alloys form thin, adhering, goldbrown layers, whereas thick, black, Fe-rich and poor adhering layers are formed on the less resistant alloys.

4. The above mentioned corrosion features are also shown by commercial $\mathrm{CuNi} 10 \mathrm{Fe}$ alloys.

Their corrosion behaviour with respect to the occurrence of a potential jump and the appearance of the corrosion layer may be attributed to a possible segregation inside these alloys. However, segregation bands with discontinuous precipitates were not found in these alloys.
In agreement with this the corrosion rates of the commercial alloys generally do not exceed those of the pure alloys with continuous precipitates, which is very low for practical applications.

5. The high $\mathrm{Fe}$-containing $\mathrm{CuNi} 5 \mathrm{FeAl}(\mathrm{Mn})$-alloys show a considerably higher corrosion resistance than the CuNi $10 \mathrm{Fe}$ alloys. The above mentioned relationship between the corrosion rate on the one hand and a potential jump and the colour of the corrosion layer on the other hand does not hold for these alloys.

\section{Acknowledgements}

The authors gratefully acknowledge the assistance of the Laboratory for Metallurgy, Technical University of Delft and the discussions with Messrs. L. Katgerman and H. Kleinjan of this department. Furthermore we thank Mr. M. Jasner from the Tube Division of the Vereinigte Deutsche Metallwerke A.G., Duisburg for the supply of various alloys.

\section{References}

1. B. C. Syrett: Corrosion 32 (1976) 242.

2. D. C. Vreeland: Materials Perform. 15 (1976) 38.

3. F. P. Isseling, J. M. Krougman, L. J. P. Drolenga: Proc. 5th Int. Congress on Marine Corrosion and Fouling, Barcelona (Spain), 19-23 May 1981, 1981, 146.

4. P. T. Gilbert: Br. Corros. J. 14 (1979) 20.

5. A. W. Tracy, A. L. Hungerford: Proc. Am. Soc. for Testing Materials 45 (1945) 591.

6. G. L. Bailey: J. Inst. Metals 77 (1951) 243.

7. W. C. Stewart, F. L. La Que: Corrosion 8 (1952) 259.

8. L. J. Swartzendruber, L. H. Bennett: Scripta Metal. 2 (1968) 93.

9. J. M. Popplewell, R. J. Hart, J. A. Ford: Corr. Science 13 (1973) 295

10. K. D. Efird: Corrosion 31 (1975) 77.

11. K. D. Efird: Corrosion 33 (1977) 347.

12. B. H. Kolster, P. L. F. Rademakers, M. Pötzschke, J. Burggraf Proc. 5th Int. Symp. on Fresh Water from the Sea, Alghero, 16-20 May, 1976, 403.

13. B. H. Kolster, P. L. F. Rademakers, K. N. Kollau: Lastechniek 42 (1976) 159.

14. P. J. Berg, R. G. de Lange: Rappont nr. $134 \mathrm{M}$, Nederlands Scheepsstudiecentrum TNO (1969).

15. D. D. Macdonald, B. C. Syrett, S. S. Wing: Corrosion 34 (1978) 289.

16. B. C. Syrett, S. S. Wing: Corrosion 36 (1980) 73.

17. M. Pourbaix: J. Electrochem. Soc. 123 (1976) $25 \mathrm{C}$

18. F. P. IJsseling, J. M. Krougman: Proc. Int. Congress on Marine Corrosion and Fouling, Juan les Pins, 14-19 June 1976, 285.

(Received: 24. 5. 1982)

W 2268 